\title{
Penerapan Fair Value dan Historical Cost Terhadap Kualitas Laporan Keuangan Pada Entitas Mikro Kecil Menengah (EMKM)
}

\section{Implementation of Fair Value and Historical Cost for Quality of Financial Statements in Micro Small Medium Enterprises (SMEs)}

\author{
Devica Pratiwi \\ Universitas Bunda Mulia \\ dpratiwi@bundamulia.ac.id
}

\begin{abstract}
Abstrak
Laporan keuangan merupakan sumber informasi atas kondisi keuangan suatu perusahaan yang diperlukan untuk memenuhi kebutuhan berbagai pihak, baik internal maupun eksternal perusahaan yang keputusannya dipengaruhi oleh laporan keuangan yang dihasilkan oleh perusahaan. Di Indonesia, baru-baru ini telah diterbitkan Standar Akuntansi Keuangan untuk Entitas Mikro Kecil Menengah atau dapat disebut SAK EMKM.

Variasi dalam komitmen perusahaan untuk meningkatkan kualitas pelaporan keuangan berdasarkan IFRS diharapkan dapat mempengaruhi manfaat positif dalam perbandingan laporan keuangan perusahaan skala besar, menenga, kecil, dan mikro. Oleh sebab itu, penelitian ini akan meneliti apakah Fair Value layak diterapkan bagi Entisas Mikro Kecil Menengah.

Prosedur yang digunakan dalam penelitian ini dengan cara kualitatif-deskriptif dan menggunakan teknik komparatif untuk membandingkan konsep fair value accounting dan konsep historical cost accounting.

Hasil dari beberapa penelitian yang diolah, mengatakan bahwa keberadaan fair value accounting cukup memberatkan bagi EMKM, karena membutuhkan waktu, tenaga, dan biaya besar dalam penyelenggaraan fair value accounting.
\end{abstract}

Kata Kunci: Nilai Wajar, EMKM, nilai wajar, harga perolehan, standar akuntansi

\section{Abstract}

The financial statements are a source of information on the financial condition of a company needed to meet the needs of various parties, both internal and external companies whose decisions are influenced by financial statements. In Indonesia, recently issued Financial Accounting Standards for Micro Small Medium Enterprises or may be called SAK EMKM. 
Variations in the firm's commitment to improve the quality of financial reporting based on IFRS are expected to affect the positive benefits in the comparison of large, medium, small, and micro corporate financial statements. Therefore, this study will examine whether Fair Value is worth applying for Micro Small Medium Enterprises (SMES).

The procedure used in this research is qualitative-descriptive and using comparative technique to compare fair value accounting concept and historical cost accounting concept.

The result of some research that is processed, said that the existence of fair value accounting is quite burdensome for EMKM, because it takes time, effort, and cost in the implementation of fair value accounting.

Keywords: SMes, Financial Reporting Standard, fair value accounting, historical cost accounting

\section{Pendahuluan}

Timbul dan berkembangnya perusahaan level multinasional, adanya pertumbuhan pasar internasional dan beberapa perubahan perilaku dari investor merupakan beberapa faktor yang mendorong proses internasionalisasi kegiatan ekonomi yang akhirnya mengakibatkan adanya kebutuhan untuk menyeragamkan standar akuntansi yang berlaku internasional. Standar akuntansi sangat diperlukan, karena tanpa standar akuntansi, masyarakat yang menggunakan laporan keuangan harus mempelajari terlebih dahulu dasar akuntansi dari masing-masing perusahaan yang kemudian membuat perbandingan dengan laporan keuangan perusahaan lainnya.

Laporan keuangan disusun berdasarkan standar akuntansi yang berlaku di suatu negara. Laporan keuangan yang disusun berdasarkan standar akuntansi yang berbeda antarnegara mempersulit investor dalam membandingkan kinerja keuangan perusahaan secara global. Apalagi di era globalisasi sekarang ini dengan aliran modal yang tidak lagi mengenal batas negara, kebutuhan akan standar akuntansi internasional yang dapat dibandingkan menjadi semakin meningkat. Hal ini terjawab dengan diberlakukannya International Financial Reporting Standard (IFRS) sebagai standar akuntansi internasional. 
Program konvergensi PSAK ke IFRS di Indonesia mendapat dukungan penuh dari pemerintah (Iskandar, 2011). Dengan konvergensi IFRS, kebutuhan standar akuntansi Indonesia yang dapat diperbandingkan dengan negara lain dapat terpenuhi. Implementasi standar akuntansi yang baru ini diharapkan dapat meningkatkan kualitas laporan keuangan yang dihasilkan, dalam hal meningkatnya komparabilitas dan transparansi laporan keuangan. Kualitas pelaporan keuangan meningkat jika konvergensi IFRS membatasi perilaku oportunistik manajemen dalam menentukan angka akuntansi (laba). Sehingga diharapkan implementasi IFRS dapat menurunkan praktik manajemen laba. Beberapa studi telah meneliti pengaruh implementasi IFRS terhadap kualitas laporan keuangan, baik di negara maju maupun di negara berkembang.

Menurut studi Barth et al. (2008), perusahaan yang mengadopsi IFRS mengalami penurunan manajemen laba, pengakuan kerugian yang lebih tepat waktu, dan relevansi nilai laba yang lebih tinggi dibandingkan sampel perusahaan yang tidak mengadopsi IFRS. Hal ini terjadi karena IFRS merupakan standar akuntansi yang berbasis prinsip (principles-based), menghilangkan alternatif perlakuan akuntansi yang sebelumnya diperbolehkan, dan mensyaratkan pengukuran akuntansi yang lebih baik dalam mencerminkan posisi dan kinerja ekonomi perusahaan saat ini atau dapat dikatakan IFRS menganut penilaian nilai wajar Fair Value.

Penelitian yang menyimpulkan adanya manfaat adopsi IFRS terhadap menurunnya manajemen laba antara lain dilakukan oleh Iatridis (2010) dan Zeghal et al (2011). Sedangkan penelitian lain yang menyimpulkan bahwa adopsi IFRS tidak berpengaruh atau bahkan meningkatkan manajemen laba antara lain didapatkan oleh Capkun et al (2012). Penelitian serupa di Indonesia dilakukan oleh Soenarno (2016) yang meneliti pengaruh adopsi IFRS terhadap manajemen laba di perusahaan manufaktur di Indonesia. Rohaeni dan Aryati (2011) meneliti pengaruh konvergensi IFRS terhadap income smoothing dengan kualitas audit sebagai variabel moderasi.

Bagi sebagian penelitian penerapan prinsip Historical Cost dan Fair Value dinilai untuk entitas tertentu, namun bagaimana dampak bagi usaha di Indonesia yang 
mayoritas memiliki entitas mikro kecil dan menengah (EMKM)? Apakah laporan keuangan yang menganut prinsip Fair Value memberatkan EMKM?

Penelitian ini bertujuan untuk mengetahui apakah penerapan IFRS yang menganut konsep Fair Value Accounting dapat memberikan pengaruh positif bagi semua jenis perusahaan yang ada di Indonesia dibandingkan dengan konsep Historical Cost Accounting, terlebih lagi bagi entitas mikro kecil dan menengah (EMKM)

\section{Kajian Literatur}

\section{Agency Theory}

Teori ini dikembangkan oleh Jensen dan Meckling (1976) yang menyatakan bahwa prinsipal (pemegang saham) dan agen (manajemen perusahaan) memiliki kepentingan yang berbeda dan cenderung akan memaksimalkan kepentingannya maisng-masing. Ada kecenderungan agen untuk menyajikan informasi yang tidak sebenarnya sehingga muncul asimetri informasi dan konflik kepentingan.

Teori keagenan melihat adanya asimetri informasi antara manajemen dengan pemegang saham. Manajemen memiliki informasi yang lebih banyak dibandingkan pemegang saham. Informasi ini digunakan untuk pengambilan keputusan baik oleh agen maupun prinsipal. Agen akan termotivasi untuk melaporkan hasil yang maksimal sesuai harapan prinsipal yang kemudian akan meningkatkan kepercayaan prinsipal kepada agen. Dengan kata lain, asimetri informasi ini akan menimbulkan kecenderungan agen dalam melakukan perilaku yang tidak seharusnya (dysfunctional behavior). Salah satu bentuk dysfunctional behavior adalah manipulasi atau manajemen laba.

\section{Fair Value Accounting}

Menurut Suwardjono $(2008 ; 475)$ fair value adalah jumlah rupiah yang disepakati untuk suatu obyek dalam suatu tranksaksi antara pihak-pihak yang berkehendak bebas tanpa tekanan atau keterpaksaan. IAI dalam buletin teknis no.3, Paragraf PA84 manyatakan bahwa: Dasar dari definisi fair value adalah asumsi bahwa entitas merupakan unit yang akan beroperasi selamanya tanpa ada intensi atau keinginan 
untuk melikuidasi, untuk membatasi secara material skala operasinya atau transaksi dengan persyaratan yang merugikan.

Berdasarkan FASB Concept Statement No. 7 dapat ditarik suatu kesimpulan bahwa fair value adalah harga yang akan diterima dalam penjualan aset atau pembayaran untuk mentransfer kewajiban dalam transaksi yang tertata antara partisipan di pasar dan tanggal pengukuran (Perdana, 2011) FASB, dalam Statement yang terbaru 157, pengukuran fair value mengesahkan fair value sebagai exit value, dengan tanda setuju dari IASB kepada beberapa reservasi minor fair value adalah harga yang akan diterima dengan menjual satu aset atau yang dibayar untuk memindahkan suatu kewajiban dalam transaksi antara peserta-peserta pasar di tanggal pengukuran (Penman, $2007 ; 33)$.

\section{Historical Cost Accounting}

Menurut Suwardjono $(2008 ; 475)$ biaya perolehan (historical cost) merupakan rupiah kesepakatan atau harga pertukaran yang telah tercatat dalam sistem pembukuan. Prinsip historical cost menghendaki digunakannya harga perolehan dalam mencatat aktiva, utang, modal dan biaya. Yang dimaksud dengan harga perolehan adalah harga pertukaran yang disetujui oleh kedua belah pihak yang tersangkut dalam tranksaksi. Harga perolehan ini harus terjadi pada seluruh transaksi diantara kedua belah pihak yang bebas. Harga pertukaran ini dapat terjadi pada seluruh tranksaksi dengan pihak ekstern, baik yang menyangkut aktiva, utang, modal dan transaksi lainnya

Konsep biaya historis (juga dikenal sebagai prinsip biaya akuntansi) menyatakan bahwa aset dan kewajiban bisnis harus disajikan dalam catatan akuntansi dengan biaya historisnya. Biaya historis adalah jumlah yang awalnya dibayarkan untuk memperoleh aset dan mungkin berbeda dari nilai pasar aset saat ini. bahwa semua aset dicatat dalam pembukuan dengan harga pembeliannya, yang meliputi biaya perolehan, pengangkutan dan pemasangan dan bukan pada harga pasarnya. Artinya, aset tetap seperti bangunan, pabrik dan mesin, perabotan, dan lain-lain dicatat dalam pembukuan dengan harga yang dibayarkan untuk mereka. 


\section{Penelitian Terdahulu}

Menurut Penelitian oleh Reddy Krishna, Locke Stuart, \& Scrimgeour Frank (2010) menunjukkan bahwa aturan yang ditetapkan oleh NZSC memiliki pengaruh positif terhadap kinerja perusahaan yang diukur dengan Tobin's Q, MB dan ROA. Selanjutnya penelitian dai Claudya Ursula, Budiharta Pratiwi (2014) membuktikan bahwa tidak terdapat perbedaan manajemen laba sebelum dan sesudah konvergensi IFRS. Hal ini terjadi karena dengan adanya principle-based yang mensyaratkan professional judgment serta adanya pembatasn metode akuntansi tidak mampu mengubah tingkat manajemen laba dan relevansi nilai informasi akuntansi meningkat setelah diberlakukannya konvergensi IFRS. Ada pula hasil penelitian dari Gao Pingyang, Sapra Haresh, \& Xue Hao (2016) yang menyatakan bahwa standar tersebut lebih bergantung pada penilaian profesional auditor karena (1) meningkatnya efetivitas penegakan peraturan, (2) biaya pengelolaan bukti meningkat, dan (3) biaya kesalahan optimisme yang tidak semestinya mengalami penurunan dan / biaya peringatan akan kesalahan mengalami peningkatan.

\section{Metode Penelitian}

Ditinjau dari jenis datanya pendekatan penelitian yang digunakan dalam penelitian ini adalah pendekatan kualitatif. Adapun yang dimaksud dengan penelitian kualitatif yaitu penelitian yang bermaksud untuk memahami fenomena tentang apa yang dialami oleh subjek penelitian secara holistik, dan dengan cara deskripsi dalam bentuk kata-kata dan bahasa, pada suatu konteks khusus yang alamiah dan dengan memanfaatkan berbagai metode ilmiah (Moleong, 2007). Adapun jenis pendekatan penelitian ini adalah deskriptif. Penelitian deskriptif yaitu penelitian yang berusaha untuk menuturkan pemecahan masalah yang ada sekarang berdasarkan data-data. Menurut Uma Sekaran (2011), studi deskriptif dilakukan untuk mengetahui dan menjadi mampu untuk menjelaskan karakteristik variabel yang diteliti dalam suatu situasi.

Dari pendapat di atas, maka dapat diketahui bahwa penelitian kualitatif-deskriptif merupakan penelitian yang digunakan apabila faktor penelitian tidak dapat dikuantifikasikan atau tidak dapat dihitung sehingga variabel tidak dapat diungkapkan dengan angka seperti persepsi, pendapat, anggapan dan sebagainya. 


\section{Hasil dan Pembahasan}

\section{Implikasi Konsep Rule Based dan Principle Based terhadap Akuntansi.}

Salah satu perbedaan pola pikir yang terjadi diantara para akuntan ialah dengan memandang bahwa GAAP (Generally Accepted Accounting Principle) adalah berbasis aturan (rule based) sedangkan IFRS (International Financial Reporting Standard) adalah berbasis prinsip (principle based). Rule-based didefinisikan sebagai ketentuan atau kriteria yang spesifik yang mencakup batasan-batasan yang sangat jelas, contohcontoh, pembatasan jangkauan, pengecualian, panduan implementasi, dan sebagainya (Wahyuni, 2011). Perilaku check-the-box dalam pelaporan keuangan untuk menghilangkan judgement dalam praktik pelaporan muncul karena rule-based memberikan aturan-aturan yang sangat detail untuk setiap aplikasi dan standar (Maines et al, 2003).

Perbedaan principle-based dengan rule-based dapat dilihat melalui standar sewa dan konsolidasi. Dalam standar sewa rule-based, yang juga dianut oleh PSAK 30 sebelum mengadopsi IFRS, pemisahan antara sewa operasi dan sewa pembiayaan sangat tegas dan detil. Suatu sewa masuk kategori sewa pembiayaan bila memenuhi beberapa syarat, misalnya masa sewa melingkupi minimal $75 \%$ dari total umur ekonomis barang sewaan. Karena batasan yang jelas ini, maka mereka yang ingin mengkategorikan sewa sebagai sewa operasi untuk menghindari pengakuan liabilitas sewa di neraca bisa “mengakali" kontrak sewa menjadi 74\% dari umur ekonomis barang sewaan. Dengan demikian mengkategorikan sewa ini sebagai sewa operasi tidaklah salah karena tidak bertentangan dengan standar akuntansi. Dalam standar sewa yang principle-based, batas 75\% tidak disebutkan tapi yang ditekankan adalah substansi sewa. Sewa dikategorikan sebagai sewa pembiayaan bila manfaat dan risiko dari barang sewaan secara substansial berpindah ke penyewa. Masa sewa bisa menjadi salah satu indikasi, tapi tidak ada garis batas jelas 75\% melainkan menggunakan penjelasan "masa sewa adalah untuk sebagian besar umur ekonomis aset", dengan demikian yang memiliki umur sewa $74 \%$ bisa dipastikan bahwa bisa dikategorikan sebagai sewa pembiayaan.

Menurut Benneth et all. (2006), principle-based standards mensyaratkan professional judgement baik pada level transaksi maupun pada level laporan keuangan. Oleh karena 
itu, IFRS dengan principle based menjadikan IFRS lebih fleksibel menghadapi perkembangan zaman dan memberikan keleluasaan yang lebih besar pada akuntan untuk menggunakan professional judgement. Namun justru hal ini membuat IFRS menyuburkan manipulasi laporan keuangan, terutama kebebasan manajer untuk melakukan manajemen laba bila dibandingkan dengan standar GAAP yang masih menggunakan rule-based membuat manajer tidak leluasa dalam melakukan praktik kecurangan akuntansi.

Banyak pandangan yang mengartikan bahwa GAAP adalah standar rule-based sehingga tidak memiliki prinsip. GAAP juga memiliki kerangka konseptual, bahkan banyak yang berpendapat kualitas kerangka konseptual GAAP lebih baik daripada IASB. Banyak faktor yang membuat perkembangan standar akuntansi GAAP yang menjadi detil dan rumit seperti sekarang ini. GAAP dikembangkan lebih dari 50 tahun dengan pendekatan bottom-up sesuai dengan kebutuhan dan permintaan pengguna standar. Sehingga standar GAAP memang makin lama semakin rumit karena perkembangan transaksi dan kompleksitas bisnis yang semakin berkembang. Ada juga yang berpendapat standar IFRS nantinya akan semakin rumit dan detil seiring dengan banyak permintaan dari pengguna standar untuk klarifikasi dan petunjuk penggunaan. Di lain pihak standar yang bersifat principle-based lebih mudah dipelajari dan dipahami karena lebih ringkas dan tidak rumit. Namun ketika terjadi banyak variasi praktik dalam bisnis, akuntan harus percaya diri dalam mengiterpretasikan standar yang principle based tersebut.

\section{Komparasi Penerapan Historical Cost dan Fair Value pada Perusahaan secara Umum}

Penelitian dari Walid Siam and Modar Abdullatif (2015) dengan objek dari perbankan di negara Jordania, menunjukkan beberapa keunggulan dan kelemahan dari penerapan fair value accounting sebagai berikut:

Keunggulan:

- FVA berisi informasi yang relevan untuk pengambilan keputusan.

- Meningkatkan akurasi dan memberikan alternatif keputusan.

- Mengurangi tingkat ketidakpastian dalam pengambilan keputusan. 
- Dapat diakses pada waktu yang tepat.

- Penerbitan laporan keuangan interim, kuartal dan tahunan menjadi lebih tepat waktu.

- Dapat digunakan untuk memprediksi kondisi dimasa depan.

- Dapat digunakan untuk mengkoreksi kejadian masa lalu.

Kelemahan:

- FVA menimbulkan ambiguitas karena banyaknya peraturan dalam IFRS.

- Rendahnya reliabilitas estimasi nilai wajar dibandingkan historical cost.

- Bersifat tidak objektif dan rentan akan kecurangan dalam LK.

- Nilai pasar tidak banyak tersedia bagi instrumen keuangan atau kondisi pasar tidak memadai.

- Hanya bergantung pada harga pasar dan penilaian dari appraisal.

Selanjutnya penelitian dari Yi-Ping Liao (2013) menjelaskan penerapan Fair Value Accounting sangat sulit untuk diterapkan dalam industri perbankan di Taiwan yang terkait dengan financial assets dan liabilities seperti trading, available for sale, dan held to maturity. Ketika aset keuangan dilaporkan dengan menggunakan Fair Value maka tingkat volatilitas pendapatan bank menjadi tidak stabil, hal ini terjadi karena CAR yang merupakan alat ukur (kontrol) yang digunakan oleh regulator untuk memantau kesehatan bank akan menghasilkan nilai yang tidak relevan jika nilai wajar atas aset keuangan tidak tersedia di pasar sehingga biaya historis menjadi lebih informatif dalam melaporkan nilai dari aset keuangan.

Yousef Shahwan (2008) dalam penelitiannya menggunakan sebuah laporan yang dinamakan sebagai Market Corporate Report Valuable (MCRV). Berdasarkan hasil dari laporan tersebut, peneliti menemukan bahwa penggunaan historical cost dalam menghitung depresiasi dalam laporan keuangan seringkali tidak dilakukan secara konsisten sehingga membuat laporan keuangan (total aset) menjadi tidak bermanfaat dan atau tidak berarti. MCRV mendukung informasi kini (fair value) dan masa depan dibandingkan dengan menggunakan informasi masa lalu karena hal tersebut dianggap lebih merepresentasikan realitas situasi ekonomi di masa depan. Penelitian oleh Leif Atle Beisland (2015) menunjukkan beberapa keunggulan fair value accounting adalah 
meningkatkan relevansi nilai buku dan mampu meningkatkan nilai dari neraca. Sedangkan kelemahan dari fair value accounting dapat mengakibatkan nilai relevansi laba menurun dan tidak memperhatikan prinsip konservatisme yang dapat meningkatkan risiko / dampak negatif bagi perusahaan

Terakhir penelitian oleh Mahesh Joshi, Prem W. Yapa dan Diane Kraal (2016) menyimpulkan bahwa para akuntan profesional yang ada di ketiga negara tersebut mendukung pengadopsian IFRS karena secara ekonomi mereka merasa sangat diuntungkan dan adanya harmonisasi dengan standar akuntansi global membuat para akuntan mudah untuk saling berbagi informasi antar satu negara dengan negara lainnya. Terlebih lagi, pengadopsian IFRS di ketiga negara tersebut juga didukung oleh pemerintah, media, dan badan akuntansi profesional lainnya.

Berdasarkan beberapa penelitian mengenai Historical Cost dan Fair Value dalam perusahaan dibeberapa negara terlihat bahwa terdapat beberapa keuntungan dari penggunaan nilai wajar seperti informasi yang disajikan mencerminkan nilai yang juga berlaku di pasar, ketepatan waktu pelaporan keuangan juga lebih tepat waktu sehingga akses akan laporan keuangan menjadi lebih mudah, menyediakan beberapa alternatif dalam pengambilan keputusan, dan dapat digunakan untuk mengkoreksi kesalahan di masa lalu. Namun, tak sedikit juga tantangan atas penerapan fair value dalam laporan keuangan seperti banyaknya aturan IFRS yang menimbulkan ambiguitas informasi, adanya pos-pos yang harus dikorbankan untuk meningkatkan beberapa pos lain dalam laporan keuangan, dan jika nilai wajar tidak tersedia di pasar maka pembuatan estimasi harus dilakukan yang mana hal itu sering sekali dikaitkan dengan unsur subjektifitas akuntan atau appraisal.

\section{Kepatuhan Akuntansi pada Entitas Mikro Kecil Menengah (EMKM).}

Dalam memahami kepatuhan pelaporan akuntansi dalam entitas mikro kecil menengah yang selanjutnya disingkat EMKM, maka akan dideskripsikan beberapa hasil penelitian yang pernah dipublikasikan beberapa waktu yang lalu. Berdasarkan penelitian Wyk dan Rossouw (2009) dengan objek penelitian di EMKM Afrika Selatan, mengungkapkan berkembangnya akuntansi yang sebelumnya menerapkan 
prinsip GAAP (Generally Accepted Accounting Practice (GAAP) dan sekarang mengadopsi Internasional Finansial Reporting Standards (IFRS) menyebabkan kekhawatiran bagi praktisi akuntansi secara global. Oleh demikian disusunlah draft IFRS for SMEs yang diharapkan dapat meringankan tekanan dalam menyiapkan laporan keuangan EMKM.

Namun berdasarkan hasil empiris yang dilakukan, ditemukan bahwa praktisi akuntansi tetap bersikap skeptis mengenai standar IFRS for SMEs ini dalam mengurangi tekanan laporan keuangan EMKM, isi dalam standar IFRS for SMEs dianggap masih terlalu luas bagi lingkungan EMKM pada industri bisnis di Afrika. Beberapa topik yang ditekankan dalam IFRS for SMEs seperti penurunan nilai aset, aset tak berwujud, aset tetap belum mampu diaplikasikan oleh EMKM secara penuh (rata-rata masih dalam persentasi dibawah 40\%). Sehingga meskipun IFRS for SMES merupakan langkah besar dalam mencapai keputusan akuntansi yang tepat, tetapi masih banyak yang harus disesuaikan agar dapat diterapkan penuh oleh EMKM di Afrika Selatan atau secara global.

Selanjutnya berdasarkan penelitian yang diungkapkan oleh Dan-Duc (2011) dengan objek penelitian pada EMKM di Vietnam, hasilnya menunjukkan bahwa keberadaan aturan/ hukum merupakan faktor utama yang mempengaruhi kepatuhan perusahaan terhadap standar akuntansi. Hasil ini mendukung temuan Yang dan Nguyen (2003) bahwa tujuan laporan keuangan oleh EMKM itu terbatas dan kendali serta peraturan pemerintah adalah pendorong utama penyusunan informasi keuangan perusahaan kecil di Vietnam. Selain itu, penelitian ini mendukung temuan Joshi dan Ramadhan (2002), di mana meskipun persepsi penggunaan informasi akuntansi eksternal bukan faktor utama yang mempengaruhi praktik pelaporan saat ini oleh EMKM, tetapi faktor ini adalah alasan utama kepatuhan perusahaan terhadap standar akuntansi. Oleh karena itu ada kebutuhan untuk meningkatkan kesadaran perusahaan kecil untuk memenuhi kebutuhan pengguna informasi keuangan mereka, daripada hanya untuk mematuhi peraturan pemerintah.

Penelitian selanjutnya dikembangkan oleh Ahn dan Nguyen (2011), diketahui perkembangan sistem akuntansi di negara Vietnam bermula berpedoman pada sistem 
Perancis di tahun sebelum 1986, kemudian beralih pada sistem negara China, dan di tahun 2001 mulai dikembangkan oleh negara Vietnam sendiri, sehingga pada tahun 2006 terdapat standar akuntansi untuk perusahaan umum, standar akuntansi untuk sektor khusus dan standar akuntansi untuk EMKM. Berdasarkan data pada tahun 2009, Vietnam merupakan salah satu negara dari 100 negara yang telah melakukan upaya menerapkan IAS. Sebagai bagian dari proses untuk mengintegrasikan Vietnam untuk lebih dekat dengan ekonomi global, sehingga dilakukan penyelarasan sistem akuntansi negara mengarah ke sistem akuntansi internasional.

Otchere dan Agbeibor (2013) juga melakukan penelitian mengenai sistem akuntansi di Ghana, dan hasilnya mengungkapkan bahwa EMKM memiliki kebutuhan terbatas terhadap IFRS for SMEs, karena struktur kegiatan internasional mereka yang terbatas serta permintaan untuk mempersiapkan laporan keuangan secara internasional. Sehingga dapat dikatakan IFRS for SMEs bukanlah standar akuntansi yang sesuai untuk bisnis usaha kecil di Ghana. Lebih dari dua pertiga dari masalah akuntansi yang dibahas di dalam IFRS for SMEs dan dievaluasi dalam penelitian saat ini sedikit banyak atau tidak relevan untuk usaha kecil di Ghana.

Berdasarkan penelitian-penelitian di atas, Standar akuntansi yang lebih disederhanakan dan disusun khusus untuk EMKM, diharapkan dapat membantu perkembangan laporan keuangan bagi entitas mikro kecil menengah (EMKM) yang dapat menghasilkan informasi tidak hanya kepada pihak internal perusahaan, tetapi juga bermanfaat bagi pihak eksternal perusahaan. Tujuan informasi keuangan EMKM oleh pihak eksternal perusahaan adalah bermanfaat ketika EMKM hendak melakukan ekspansi usaha mereka dan memerlukan tambahan modal dari luar. Selain itu, bila EMKM juga hendak merintis usaha mereka menuju skala yang lebih besar, maka transisi EMKM dalam penyesuaian kegiatan finansial terutama dalam persiapan laporan keuangan dan informasi lain, bukanlah langkah yang sulit karena standar akuntansi khusus EMKM yang ada disesuaikan dengan standar akuntansi internasional. 


\section{Analisis Penerapan Historical Cost dan Fair Value pada Entitas Mikro Kecil Menengah (EMKM).}

Berdasarkan penjelasan sebelumnya, penerapan fair value accounting memberikan dampak positif berupa informasi yang relevan untuk pengambilan keputusan, meningkatkan akurasi dan memberikan alternatif keputusan, dapat diakses pada waktu yang tepat dan penerbitan laporan keuangan interim, kuartal dan tahunan menjadi lebih tepat waktu. Sehingga bagi beberapa entitas umum lebih mendukung informasi kini (fair value) dan masa depan dibandingkan dengan menggunakan informasi masa lalu karena hal tersebut dianggap lebih merepresentasikan realitas situasi ekonomi di masa depan. Disisi lain, sisi negatif dari penerapan fair value accounting lebih mengarah pada menimbulkan ambiguitas karena banyaknya peraturan dalam IFRS, bersifat tidak objektif dan rentan akan kecurangan dalam LK, nilai pasar tidak banyak tersedia bagi instrumen keuangan atau kondisi pasar tidak memadai dan tidak memperhatikan prinsip konservatisme yang dapat meningkatkan risiko / dampak negatif bagi perusahaan.

Sehingga bila dikaitkan dengan EMKM yang dianjurkan untuk menerapkan fair value accounting, dapat dikatakan lebih banyak kelemahan dibanding keuntungan. Menurut Bank Dunia, EMKM dapat dikelompokkan dalam tiga jenis, yaitu: 1. Usaha Mikro (jumlah karyawan 10 orang); 2. Usaha Kecil (jumlah karyawan 30 orang); dan 3. Usaha Menengah (jumlah karyawan hingga 300 orang).

Dalam perspektif usaha, EMKM diklasifikasikan dalam empat kelompok, yaitu:

- EMKM sektor informal, contohnya pedagang kaki lima.

- EMKM Mikro adalah para EMKM dengan kemampuan sifat pengrajin namun kurang memiliki jiwa kewirausahaan untuk mengembangkan usahanya.

- Usaha Kecil Dinamis adalah kelompok EMKM yang mampu berwirausaha dengan menjalin kerjasama (menerima pekerjaan sub kontrak) dan ekspor.

- Fast Moving Enterprise adalah EMKM yangmempunyai kewirausahaan yang cakap dan telah siap bertransformasi menjadi usaha besar.

Penerapan fair value accounting lebih disarankan kepada EMKM dengan klasifikasi Fast Moving Enterprise karena usaha ini adalah yang paling siap untuk menjadi 
perusahaan besar. Bila dibanding ketiga tipe lainnya, EMKM sektor informal dan mikro dianggap belum memisahkan keuangan keluarga dengan keuangan usaha, sedangkan usaha kecil dinamis baru saja memulai administrasi keuangan meskipun sederhana, maka sulit bagi mereka apabila diharuskan untuk menerapkan fair value accounting yang pada dasarnya juga sulit dilakukan oleh perusahaan besar. Keberadaan standar akuntansi untuk EMKM internasional yang dikenal sebagai IFRS for SMEs juga belum mampu mengatasi keuangan bagi EMKM yang tersebar di dunia, dikarenakan sikap skeptis praktisi akuntan dalam menganggapi keberadaan IFRS for SMEs untuk mengurangi tekanan EMKM dalam menyusun laporan keuangan (Wyk dan Rossouw, 2009). Sehingga dapat disimpulkan juga keberadaan IFRS for SMES hanya dapat diterapkan bagi tipe EMKM tertentu dan bidang usaha tertentu saja.

Perusahaan besar yang mulai menerapkan fair value accounting memerlukan dana yang tidak sedikit, waktu yang relatif lama dan pihak ahli untuk dapat mengadopsi sistem ini secara penuh. Bila dibandingkan dengan EMKM yang memiliki modal terbatas, aset yang tergolong kecil dan laporan keuangan sederhana, maka sulit bagi mereka untuk menerapkannya. Kemudian prioritas EMKM untuk menerapkan fair value accounting juga belum dapat dibilang suatu kewajiban, karena sistem ini hanya membantu perusahaan publik untuk memberi informasi keuangan yang aktual bagi pengguna eksternal, sedangkan EMKM umumnya menyiapkan laporan keuangan hanyak untuk internal saja.

\section{Daftar Pustaka}

Ahn, Doan Ngoc Phi \& Duc-Toh Nguyen. (2011). Accounting in Developing Transitional Economy: The Case of Vietnam. Asian Review of Accounting, Vol. 21, Issue 1: pp.74-95.

Barth, M., Landsman, W., Lang, M. (2008). International accounting standards and accounting quality. J. Account. Res. 46 (3), 467-498.

Beisland, L.A., and Knivsla, K.H. (2015). Have IFRS Changed How Stock Price are Associated with Earnings and Book Values?: Evidence from Norway. Review of Accounting and Finance, Vol. 14, Iss: 1, pp: 41-63.

Capkun, V., Collins, D., Jeanjean, T. (2012). Does adoption of IAS/IFRS deter earnings management? Working paper, University of Iowa. HEC Paris, and ESSEC Business School.

Claudya, U., dan Budiharta, P. (2014). Analisis Perbedaan Kualitas Akuntansi Sebelum dan Sesudah Konvergensi IFRS. E-Journal Universitas Atmajaya Yogya. 
Dan-Duc, Son. (2011). Compliance with Accounting Standards by SMEs in Transitional Economies: Evidence from Vietnam. Journal of Applied Accounting Research, Vol 12, Issue 2, pp. 96-107.

Gao, P., Sapra, H., and Xue, H. (2016). A Model of Principles-Based vs Rules-Based Standards. Accounting Workshop.

Jensen C. Michael C. Meckling H. William. (1976). Theory of the firm: Managerial behavior, agency costs and ownership structure. Journal of Financial Economics 3, 305-360.

Joshi, P.L. and Ramadhan, S. (2002). The Adoption of International Accounting Standards by Small and Closely Held Companies: Evidence from Bahrain. The International Journal of Accounting, Vol. 37 No. 4, pp. 429-40.

Liao, Ping. (2013). The Impact of Fair-Value-Accounting on the Relevance of Capital Adequacy Ratios: Evidences from Taiwan. Journal of Managerial Finance, Vol. 39 Iss: 2, pp. 133-154.

Moleong, Lexy J. (2007) Metodologi Penelitian Kualitatif. Bandung: PT. Remaja Rosdakarya Offset.

Otchere, Francis Aboagye \& Juliet Agbeibor. (2013). The International Financial Reporting Standard for Small Medium-Size Entities (IFRS for SMEs): Sustainability for Business in Ghana. Journal of Financial Reporting and Accounting, Vol. 10, Issue 2, pp. 192-214.

Prem, M.J.P., and Kraal, S.Y.D. (2016). IFRS Adoption in ASEAN Countries". International Journal of Managerial Finance, Vol. 12 Iss: 2, pp. 211-240.

Reddy, K., Locke, S., and Scrimgeour, F. (2010). The Efficacy of Principle-Based Corporate Governance Practices and Firm Financial Performance: an Empirical Investigation. International Journal of Managerial Finance, Vol. 6, Iss: 3, pp. 190-219.

Rohaeni, Dian dan Aryati, Titik. (2011). Pengaruh Konvergensi IFRS terhadap Income Smoothing dengan Kualitas Audit sebagai Variabel Moderasi. Simposium Nasional Akuntansi XV.

Shahwan, Yousef. (2008). Qualitative Characteristics of Financial Reporting: a Historical Perspective. Journal of Applied Accounting Research, Vol. 9 Iss: 3, pp. 192-202.

Siam, Walid and Abdullatif, M. (2015). Fair Value Accounting Usefullness and Implementation Obstacles: Views from Banker Jordan. Journal of Accounting in Asia, pp 83-107.

Soenarno, Yanuar Nonok. (2016)). Earning Management and IFRS Adoption: Study Case in Indonesian Manufacturing Company. 6th Annual International Conference on Accounting and Finance.

Suwardjono. (2008). Teori Akuntansi: Perekayasaan Laporan Keuangan. Yogyakarta: BPFE.

Uma, Sekaran. (2011). Research Method of Business. Jakarta: Salemba Empat.

Wyk, H.A. Van, J. Rossouw. (2009). IFRS for SMEs in South Africa: a giant leap for accounting, but too big for smaller entities in general. Meditari Accountancy Rsearch, Vol. 17 Issue: 1, pp.99-116

Zeghal, D., Chtourou, S.M. dan Fourati, Y.M. (2012). The effect of mandatory adoption of IFRS on earnings quality: evidence from the European Union. Journal of International Accounting Research, Vol. 11 No. 2, pp. 1-25. 